Биоконтроль и биозащита

\title{
БИОЛОГИЧЕСКОЕ ОБОСНОВАНИЕ ИСПОЛЬЗОВАНИЯ ИНДУКТОРОВ УСТОЙЧИВОСТИ НА ОСНОВЕ ХИТОЗАНА ДЛЯ ПОВЫШЕНИЯ ЭФФЕКТИВНОСТИ БИОФУНГИЦИДОВ
}

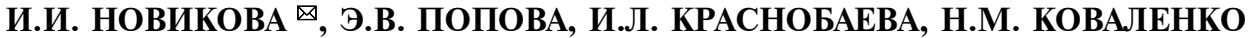

Микробиологические препараты составляют основу современных технологий фитосанитарной оптимизации агроэкосистем, поэтому повышение их эффективности в защите сельскохозяйственных культур от широкого спектра фитопатогенов - актуальная задача растениеводства. Во Всероссийском НИИ защиты растений (ФГБНУ ВИЗР) разработан биопрепарат Витаплан на основе композиции двух штаммов - Bacillus subtilis BKM В-2604D и B. subtilis BKM В-2605D с различным составом активных комплексов и механизмом действия, обладающих высокой эффективностью по отношению к широкому кругу фитопатогенов. В настоящей работе впервые получены две новые оптимизированные препаративные формы (Витаплан, КЖ + коллоидный хитин и композиция Витаплан, КЖ + 0,1 \% салицилата хитозана) с повышенной антагонистической и элиситорной активностью по сравнению с исходной формой биопрепарата. Установлено, что присутствие в новой препаративной форме Витаплана, КЖ салицилата хитозана повышает индуцирующую активность в $2,0-2,5$ раза по сравнению с исходной формой. Цель наших исследований состояла в совершенствовании подходов к повышению эффективности полифункционального биопрепарата Витаплан посредством включения в препаративную форму индукторов болезнеустойчивости на основе хитозана. Схема опыта для определения антагонистической активности в отношении Alternaria solani Sorauer и Clavibacter michiganensis subsp. michiganensis (Smith) Davisetal. (штамм 101) предусматривала следующие варианты: Витаплан, КЖ (титр жизнеспособных клеток $10^{10}$ КОЕ/мл) - культуральная жидкость штаммов B. subtilis BKM В-2604D и B. subtilis ВКМ В-2605D при соотношении 1:1 без добавок (контроль); Витаплан, КЖ (1010 КОЕ/мл) + сухой хитин $(1,0 \%) ;$ Витаплан, КЖ $\left(10^{10} \mathrm{KOE} /\right.$ мл) + коллоидный хитин $(1,0 \%$, расчет на сухую массу хитина); Витаплан, КЖ (10 ${ }^{10} \mathrm{KOE} /$ мл $)+$ коллоидный хитозан $(1,0 \%$, расчет на сухую массу хитозана). Антагонистическую активность оценивали методом бумажных дисков по диаметру зоны лизиса тест-культур фитопатогенов на агаризованной питательной среде. Фунгистатическую активность по отношению к Cochliobolus sativus $\mathrm{S}$. Ito \& Kurib. оценивали по следующий схеме: контроль (вода); Витаплан, КЖ (1010 КОЕ/мл); Витаплан, КЖ (разведение $1: 10,10^{9}$ КОЕ/мл); Витаплан, КЖ (без разведения, $10^{10} \mathrm{KOE} /$ мл) + коллоидный хитин $(1,0 \%$, расчет на сухую массу хитина); Витаплан, КЖ (разведение $1: 10,10^{9}$ КОЕ/мл) + салицилат хитозана $(0,1 \%)$; салицилат хитозана $(0,1 \%)$. Прямое фунгистатическое действие исследуемых препаративных форм оценивали in vitro методом агаровых блоков. Для изучения индуцирующей активности в патосистеме пшеница (Triticum aestivum L.) - C. sativus отобранные варианты (Витаплан, КЖ; Витаплан КЖ + 1 \% коллоидный хитин; композиция Витаплан, КЖ + 0,1 \% салицилат хитозана) разводили дистиллированной водой в 10 раз, титр рабочего раствора составлял $10^{9} \mathrm{KOE} /$ мл. За 24 ч до инокуляции патогеном 7-суточные проростки пшеницы восприимчивого к болезням сорта Саратовская 29 опрыскивали суспензиями образцов препаративных форм при разведении 1:10. Листья пшеницы заражали суспензией спор гемибиотрофа C. sativus $\left(4 \times 10^{3}\right.$ и $20 \times 10^{3}$ спор/мл). Степень пораженности листьев оценивали на 4-е сут после заражения в процентах по площади листа. В контроле растения обрабатывали водой. Введение коллоидного хитина $(1,0 \%)$ в среду для глубинного культивирования штаммов-продуцентов B. subtilis BKM В2604D и BKM B-2605D повышало их антагонистическую активность в отношении возбудителей бактериального рака томата и альтернариоза томата, а также обеспечивало эффективное подавление роста мицелия возбудителя темно-бурой пятнистости пшеницы C. sativus до 84,9 и 88,1 \% соответственно на 5-е и 7-е сут опыта, сравнимое с эффективностью Витаплана, КЖ (80,9 и $87,5 \%)$. Салицилат хитозана $(0,1 \%)$ обладал умеренной фунгистатической активностью, ингибируя рост мицелия гриба $C$. sativus только на 36,5 и 46,0 \%. Предварительное опрыскивание растений пшеницы Витапланом, КЖ в разведении 1:10 с последующим заражением возбудителем темно-бурой пятнистости снижало площадь поражения листьев до 50-80 \% в зависимости от инфекционной нагрузки по сравнению с 65-100\% в контроле. Включение в среду для культивирования штаммов-продуцентов коллоидного хитина $(0,5 \%)$ сокращало пораженность листьев до 40-50 \%. Салицилат хитозана показал себя эффективным индуктором болезнеустойчивости, снизив пораженность растений пшеницы темно-бурой пятнистостью до 10-20\% в зависимости от инфекционной нагрузки. Добавление салицилата хитозана $(0,1 \%)$ в Витаплан, КЖ в разведении 1:10 также положительно влияло на индуцирующую активность антагониста, повышая его биоло- 
гическую активность в 2,0-2,5 раза. Таким образом, обоснована и экспериментально доказана перспективность сочетания активных отселектированных штаммов микроорганизмов - антагонистов возбудителей болезней растений и хитозановых комплексов для повышения биологической эффективности и расширения спектра действия разрабатываемых препаративных форм.

Ключевые слова: биопрепарат Витаплан, препаративные формы, фунгистатическая активность, антагонистический эффект, хитозан, хитин, индуцированная устойчивость, пшеница, темно-бурая пятнистость.

Традиционное интенсивное земледелие XX века было основано на широком применении химических средств защиты растений и минеральных удобрений. Однако, повысив урожайность, интенсивные технологии привели к ухудшению фитосанитарного состояния посевов вследствие формирования резистентных к пестицидам популяций вредных видов, снижению качества продукции, деградации почв и падению почвенного плодородия. В связи с этим разработка новых биологических средств защиты сельскохозяйственных культур от вредных организмов - одно из важных направлений современной сельскохозяйственной науки. Экологически безопасное растениеводство должно обеспечивать снижение химической нагрузки на агроэкосистемы, оптимизацию структуры почвенной микрофлоры и восстановление микробиологической активности почвы.

Основной элемент современных биологизированных технологий фитосанитарной оптимизации агроэкосистем - микробиологические препараты. Согласно многочисленным исследованиям, бактерии рода Bacillus Cohn. - одна из наиболее перспективных групп микроорганизмов для биологического контроля популяций фитопатогенных видов (1-4).

Биопрепараты на основе штаммов B. subtilis в борьбе с болезнями растений на основных сельскохозяйственных культурах успешно используются в России и за рубежом. Штаммы бацилл подавляли распространение и развитие фузариозного увядания кукурузы (5), фузариоза колоса пшеницы $(6,7)$, фузариозную и офиоболезную корневую гниль (8), мучнистую росу (9), желтую и бурую ржавчину зерновых культур (10-12). Пораженность риса листовыми болезнями существенно снижалась при использовании биопрепаратов на основе этой группы бактерий-антагонистов (13). На овощных культурах штаммы B. subtilis показали активность против фузариозного и бактериозного увядания томата $(14,15)$, корневой гнили огурца (16) и фитофтороза перца (17). Бациллы использовали для защиты земляники от ржавчины (18). Проблемы и перспективы применения биопрепаратов на основе штаммов B. subtilis в сельском хозяйстве рассматриваются в ряде обзоров (19-21).

Эффективность контроля плотности популяций фитопатогенов при использовании микробиологических средств защиты растений зависит от биологических особенностей штаммов-продуцентов и обусловлена рядом факторов. К ним относятся как успешная конкуренция за питательные вещества и пространство для колонизации почвы и ризосферы (22-23), так и способность микроорганизмов синтезировать биологически активные соединения (антибиотики, биосурфактанты, сидерофоры и др.) (24-26). Важное значение имеет образование гидролитических ферментов (хитиназ, глюканаз, протеаз и липаз), которые разрушают клеточные стенки фитопатогенных грибов (26). Помимо прямого антагонистического действия на клетки возбудителя болезни, бациллы способны повышать болезнеустойчивость растений благодаря наличию бактериальных детерминант (microbe-associated molecular patterns, MAMPs), таких как флагеллин, липополисахариды (ЛПС) и другие соединения, ассоциированные с клеточной стенкой B. subtilis (27-29), а также летучие органические вещества (30). 
Благодаря синтезу соединений-элиситоров активируется индуцированная устойчивость растений. Элиситоры индуцируют неспецифический иммунный ответ, но также стимулируют выработку фитогормонов - салициловой кислоты (активатор системной индуцированной устойчивости) и жасмоновой кислоты (активатор системной приобретенной устойчивости).

Штаммы бацилл, используемые в качестве основы биопрепаратов, характеризуются многообразием метаболических процессов и способны к синтезу биологически активных веществ (БАВ), различающихся по химической природе и механизму действия. В этой связи весьма перспективно создание композиций из разных штаммов или видов микроорганизмов, что может обеспечить разнообразие и высокую активность препаратов.

Во Всероссийском НИИ защиты растений (ФГБНУ ВИЗР) разработан биопрепарат Витаплан на основе композиции двух штаммов B. subtilis BKM B-2604D и B. subtilis BKM B-2605D с разным составом активных комплексов и механизмом действия, обладающих высокой эффективностью по отношению к широкому кругу фитопатогенов $(4,31)$.

Для повышения эффективности биопрепаратов заслуживает внимания подход, связанный с усилением способности бактерий запускать каскад защитных реакций и повышать системную устойчивость растений. Усиление индуцирующей активности штамма-продуцента может быть достигнуто посредством включения природных или синтетических активаторов болезнеустойчивости в состав его препаративной формы. Для этого наиболее подходят природные индукторы - полисахариды (хитин, хитозан), а также салициловая кислота (СK) как сигнальная молекула системной приобретенной устойчивости. Хитозан и препараты на его основе широко используют в защите растений от болезней в качестве индукторов неспецифической устойчивости (32-34), а СК представляет собой классический индуктор устойчивости к болезням, играющий центральную роль в защите растений от биотрофных патогенов (35).

Биопрепарат Витаплан включен в «Государственный каталог пестицидов и агрохимикатов, разрешенных для использования на территории РФ» в форме смачивающегося порошка (СП). При разработке новых полифункциональных форм были приняты во внимание полученные ранее данные о высокой иммуномодулирующей активности конъюгата хитозана с СК (салицилат хитозана) (36).

В настоящей работе впервые получены две новые оптимизированные препаративные формы Витаплана, КЖ (Витаплан, КЖ + коллоидный хитин и композиция Витаплан, КЖ + 0,1 \% салицилата хитозана) с повышенной антагонистической и элиситорной активностью по сравнению с исходной формой биопрепарата. Установлено, что присутствие в новой препаративной форме Витаплана, КЖ салицилата хитозана повышает индуцирующую активность в 2,0-2,5 раза по сравнению с исходной формой.

Цель наших исследований состояла в совершенствовании подходов к повышению эффективности полифункционального биопрепарата Витаплан посредством включения в препаративную форму индукторов болезнеустойчивости на основе хитозана.

Meтодика. В экспериментах использовали штаммы B. subtilis BKM B-2604D и B. subtilis BKM B-2605D (Государственная коллекция микроорганизмов, патогенных для растений и их вредителей, Центр коллективного пользования научным оборудованием «Инновационные технологии защиты растений» ФГБНУ ВИЗР; коллекция зарегистрирована 28 января 1998 года под № 760 в World Federation for Culture Collections, World Data 
Centre for Microorganisms - WFCC WDCM, Япония). Штаммы культивировали на искусственной питательной среде (30 г/л кукурузного экстракта, 15 г/л мелассы, pH 7,2) на лабораторной качалке при $28{ }^{\circ} \mathrm{C}$ и 220 об/мин в течение 72 ч (объем колб - 750 мл, объем среды - 100 мл).

Схема опыта для определения антагонистической активности в отношении Alternaria solani Sorauer и Clavibacter michiganensis subsp. Michiganensis (Smith) Davisetal. (штамм 101) предусматривала следующие варианты: Витаплан, КЖ (титр жизнеспособных клеток $10^{10} \mathrm{KOE} / \mathrm{Mл)} \mathrm{-}$ культуральная жидкость штаммов B. subtilis BKM B-2604D и B. subtilis BКМ В-2605D при соотношении 1:1 без добавок (контроль); Витаплан, КЖ $\left(10^{10} \mathrm{KOE} /\right.$ мл) + сухой хитин $(1,0 \%)$; Витаплан, КЖ $\left(10^{10} \mathrm{KOE} /\right.$ мл.) + коллоидный хитин (1,0\%, расчет на сухую массу хитина); Витаплан, КЖ $\left(10^{10} \mathrm{KOE} /\right.$ мл) + коллоидный хитозан $(1,0 \%$, расчет на сухую массу хитозана).

Фунгистатическую активность по отношению к Cochliobolus sativus S. Ito \& Kurib. Drechsler ex Dastur (=Bipolaris sorokiniana, =Drechslera sorokiniana Subram et Jain, =Helminthosporium sativum Раm.) оценивали по следующий схеме: контроль (вода); Витаплан, КЖ (1010 КОЕ/мл); Витаплан, КЖ (разведение дистиллированной водой 1:10, $\left.10^{9} \mathrm{KOE} / \mathrm{M}\right) ;$ Витаплан, КЖ (без разведения, $10^{10}$ КОЕ/мл) + коллоидный хитин $(1,0 \%$, расчет на сухую массу хитина); Витаплан, КЖ (разведение дистиллированной водой $\left.1: 10,10^{9} \mathrm{KOE} / \mathrm{M}\right)$ + салицилат хитозана $(0,1 \%)$; салицилат хитозана $(0,1 \%)$.

Для изучения индуцирующей активности в патосистеме пшеница (Triticum aestivum L.) - C. sativus отобранные варианты (Витаплан, КЖ; Витаплан КЖ + 1 \% коллоидный хитин; композиция Витаплан, КЖ + 0,1\% салицилат хитозана) разводили дистиллированной водой в 10 раз (в соответствии с нормами применения биопрепарата Витаплан КЖ), титр рабочего раствора во всех вариантах составлял $10^{9} \mathrm{KOE} /$ мл. Салицилат хитозана использовали в концентрации $0,1 \%$.

Коллоидный хитин получали из хитина с молекулярной массой 100 кДа растворением в концентрированной соляной кислоте с последующим осаждением ацетоном (38). Коллоидный хитозан получали разработанным нами методом. Для этого 1 г сухого хитозана (100 кДа) растворяли в 100 мл 2,5 \% водного раствора молочной кислоты при постоянном перемешивании. Далее раствор нейтрализовали $1,5 \%$ водным раствором гидроксида натрия до рН 8,0. Коллоидный раствор хитозана выдерживали в холодильнике для формирования осадка.

Хитозан (60 кДа) получали методом окислительной деструкции (37) из хитозана с молекулярной массой 150 кДа и степенью деацетилирования $85 \%$ («Биопрогресс», Россия). На его основе синтезировали салицилат хитозана, содержащий ионно-связанные фрагменты СК, составлявшие $25 \%$. Образование соли между хитозаном и СК было подтверждено наличием в ИК-спектре характеристических полос от карбоксилатной группы $\mathrm{CO}_{2}^{-}-1552,92 \mathrm{~cm}^{-1}$ и 1386,12 cм-1. Широкая сильная полоса в области 3100-2600 $\mathrm{cm}^{-1}$ соответствовала валентным колебаниям от функциональных групп $\mathrm{NH}_{3}{ }^{+}$и $\mathrm{OH}^{-}$.

Титр жизнеспособных клеток в образцах препаративных форм определяли стандартным методом 10-кратных серийных разведений с высевом на агаризованную среду СПА и последующим подсчетом выросших колоний. Антибактериальную активность образцов против возбудителя бактериального рака томатов Clavibacter michiganensis subsp. michiganensis 
(Smith) Davisetal. (штамм 101) и антигрибную активность против возбудителю альтернариоза томата Alternaria solani Sorauer оценивали методом бумажных дисков по диаметру зоны лизиса тест-культур фитопатогенов на агаризованной питательной среде. Для этого агар Чапека в чашках Петри засевали сплошным газоном тест-культуры, используя суспензию с титром $10^{5} \mathrm{KOE} /$ мл, а затем на поверхность агара помещали стерильные бумажные фильтры диаметром 8 мм, на которые пипеткой наносили суспензию лабораторного образца препаративной формы определенной концентрации. Тест-культуры выращивали в термостате ТС-1/80 СПУ (СКТБ СПУ, Россия) при $22-25{ }^{\circ} \mathrm{C}$ в течение $3-5$ сут.

Прямое фунгистатическое действие исследуемых препаративных форм оценивали in vitro методом агаровых блоков. В стерильные чашки Петри разливали охлажденную до $40{ }^{\circ} \mathrm{C}$ агаризованную среду Чапека. После застывания на поверхность среды равномерно наносили суспензии испытуемых образцов препаративных форм (0,2 мл), а затем помещали блоки 10-суточных культур возбудителя гельминтоспориозной корневой гнили зерновых культур C. sativus диаметром 6 мм, которые вырезали стерильным сверлом из мицелиальных газонов гриба, выращенных на агаре Чапека в течение 8-10 сут. Контролем служили чашки с агаризованной средой Чапека с блоками тест-культуры без образцов препаративных форм. Чашки инкубировали в темноте при $25^{\circ} \mathrm{C}$. Диаметры колоний гриба измеряли на 5-е и 7-е сут совместного культивирования, после чего оценивали фунгистатическое действие испытуемых образцов по формуле Эббота: $\Pi=Д_{к}-Д_{о п} / Д_{\mathrm{K}} \times 100 \%$, где $\Pi$ - подавление роста гриба по сравнению с контролем, \%; Дк - диаметр колонии гриба в контроле, мм; Доп - диаметр колонии гриба в опыте, мм.

Опыты по оценке иммуномодулирующей активности образцов препаративных форм проводили методом отделенных листьев (39). За 24 ч до инокуляции патогеном 7-суточные проростки пшеницы восприимчивого к болезням сорта Саратовская 29 опрыскивали суспензиями образцов препаративных форм при разведении 1:10. Листья пшеницы заражали суспензией спор гемибиотрофа $C$. sativus $\left(4 \times 10^{3}\right.$ и $20 \times 10^{3}$ спор/мл). Степень пораженности листьев оценивали на 4-е сут после заражения в процентах по площади листа. В контроле растения обрабатывали водой.

Все опыты проводили в 3-кратной повторности. Для обработки полученных данных использовали дисперсионный анализ в программах Statistica 6.0 («StatSoft, Inc.», США) и Excel 2016. При расчетах применили методы параметрической статистки на основе средних значений $(M)$ и стандартных ошибок средних $( \pm \mathrm{SEM}), 95$ \% доверительных интервалов, наименьшей существенной разности НСР при $\mathrm{p}<0,05(\mathrm{HCP} 05)$.

Результаты. Включение различных форм хитина и хитозана в среду при глубинном культивировании штаммов B. subtilis BKM B-2604D и B. subtilis BKM B-2605D не оказало отрицательного влияния на титр клеток штаммов-продуцентов биопрепарата Витаплан, КЖ (табл. 1). Установлено, что введение коллоидного хитина в среду несколько повышало антагонистическую активность штаммов-продуцентов в отношении обеих тест-культур.

Выявлена высокая фунгистатическая активность Витаплана, КЖ, которая существенно не различалась при плотности суспензии клеток $10^{9}$ и $10^{10} \mathrm{KOE} /$ мл: рост мицелия $C$. sativus подавлялся соответственно на 74,3 и $80,9 \%$ на 5-е сут и на 81,2 и 87,5 \% на 7-е сут опыта. При добавлении $1,0 \%$ коллоидного хитина в среду для культивирования штаммов биоло- 
гическая активность оставалась высокой - 84,9 и 88,1 \% соответственно на 5-е и 7-е сут. Салицилат хитозана в концентрации $0,1 \%$ обладал умеренной фунгистатической активностью, ингибируя рост мицелия гриба C. sativus на 30,5 и 42,5\%. Следует отметить, что включение салицилата хитозана в разбавленную культуральную жидкость штаммов-продуцентов в концентрации 0,1 \% приводило к незначительному снижению прямого ингибирующего действия мицелиального роста гриба C. sativus - до 61,9 и 69,4\% (табл. 2).

1. Антагонистическая активность штаммов Bacillus subtilis BKM B-2604D и B. subtilis BKM B-2605D при глубинном культивировании и введении в состав питательной среды хитина и хитозана $(M \pm S E M)$

\begin{tabular}{|c|c|c|}
\hline \multirow[b]{2}{*}{ Вариант опыта } & \multicolumn{2}{|c|}{ Диаметр зоны отсутствия роста тест-культур, мм } \\
\hline & Alternaria solani & $\begin{array}{l}\text { Clavibacter michiganensis } \\
\text { subsp. michiganensis } 101\end{array}$ \\
\hline Витаплан, КЖ без добавок (контроль) & $40,3 \pm 1,0$ & $31,9 \pm 1,0$ \\
\hline Витаплан, КЖ + сухой хитин $(1,0 \%)$ & $37,8 \pm 0,5$ & $31,9 \pm 1,2$ \\
\hline Витаплан, КЖ + коллоидный хитин (1,0%) & $43,6 \pm 0,8$ & $34,8 \pm 1,8$ \\
\hline Витаплан, КЖ + коллоидный хитозан $(1,0 \%)$ & $36,0 \pm 1,0$ & $31,6 \pm 0,5$ \\
\hline $\mathrm{HCP} 05$ & 1,1 & 0,9 \\
\hline
\end{tabular}

2. Интенсивность линейного роста тест-культуры фитопатогенного гриба Cochliobolus sativus под влиянием различных препаративных форм Витаплана, КЖ в зависимости от времени культивирования $(M \pm \mathrm{SEM})$

\begin{tabular}{|c|c|c|c|c|c|c|}
\hline \multirow[b]{2}{*}{ Вариант опыта } & \multirow{2}{*}{$\begin{array}{l}\text { Концентрация } \\
\text { дополнительного } \\
\text { компонента, \% }\end{array}$} & \multirow{2}{*}{$\begin{array}{l}\text { Титр жиз- } \\
\text { неспособ- } \\
\text { ных клеток, } \\
\text { КОЕ/мл }\end{array}$} & \multicolumn{2}{|c|}{ 5-e сут } & \multicolumn{2}{|c|}{ 7-е сут } \\
\hline & & & $\begin{array}{l}\text { диаметр } \\
\text { колоний, } \\
\text { мм }\end{array}$ & $\begin{array}{l}\text { ингиби- } \\
\text { рование } \\
\text { роста, \% }\end{array}$ & $\begin{array}{l}\text { диаметр } \\
\text { колоний, } \\
\text { мм }\end{array}$ & $\begin{array}{l}\text { ингиби- } \\
\text { рование } \\
\text { роста, \% }\end{array}$ \\
\hline Контроль (вода) & & & $52,5 \pm 0,5$ & - & $80,0 \pm 1,2$ & - \\
\hline Витаплан, КЖ & & $10^{10}$ & $10,0 \pm 0,5$ & 80,9 & $10,0 \pm 1,0$ & 87,5 \\
\hline Витаплан, КЖ (разведение & & & & & & \\
\hline $1: 10)$ & & $10^{9}$ & $13,5 \pm 0,5$ & 74,3 & $15,0 \pm 1,2$ & 81,2 \\
\hline $\begin{array}{l}\text { Витаплан, КЖ + коллоид- } \\
\text { ный хитин }\end{array}$ & 1,0 & $10^{10}$ & $8,0 \pm 0,2$ & 84,9 & $9,5 \pm 1,0$ & 88,1 \\
\hline Витаплан, КЖ (разведение & 0,1 & & & & & \\
\hline 1:10) + салицилат хитозана & & $10^{9}$ & $20,0 \pm 1,5$ & 61,9 & $24,5 \pm 1,5$ & 69,4 \\
\hline Салицилат хитозана & 0,1 & & $36,5 \pm 2,2$ & 30,5 & $46,0 \pm 2,0$ & 42,5 \\
\hline $\mathrm{HCP} 05$ & & & & 1,3 & & 0,6 \\
\hline
\end{tabular}

При заражении листьев пшеницы восприимчивого к болезням сорта Саратовская 29 суспензией спор C. sativus в контроле признаки болезни наблюдались в виде бурых пятен, занимающих 65 и 100 \% площади листа при инфекционной нагрузке патогена соответственно $4 \times 10^{3}$ и $20 \times 10^{3}$ спор/мл (рис.). Предварительное опрыскивание растений Витапланом, КЖ в разведении 1:10 с последующим заражением возбудителем темно-бурой пятнистости снижало площадь поражения листьев до 50 и $80 \%$ в зависимости от инфекционной нагрузки патогена.

Включение в среду для культивирования штаммов-продуцентов коллоидного хитина в концентрации 1,0 \% сокращало пораженность листьев до 40 и $50 \%$ при инфекционной нагрузке $4 \times 10^{3}$ и $20 \times 10^{3}$ спор/мл, что свидетельствует о более высокой иммуномодулирующей активности этой препаративной формы по сравнению с Витапланом, КЖ в разведении 1:10. Эффективным индуктором болезнеустойчивости показал себя салицилат хитозана, снизив пораженность растений до 10 и $20 \%$. Добавление в Витаплан, КЖ в разведении 1:10 салицилата хитозана в концентрации 0,1 \% также положительно влияло на индуцирующую активность антагониста, повышая его биологическую активность в 2,0-2,5 ра- 
за (поражение листьев 20 и $40 \%$ при инфекционной нагрузке $4 \times 10^{3}$ и $20 \times 10^{3}$ спор/мл) (см. рис.).

Анализ полученных данных показал, что действие препаративных форм Витаплана против темно-бурой пятнистости зависит от интенсивности поражения растений пшеницы возбудителем болезни C. sativus. Наибольший защитный эффект проявил Витаплан, КЖ в разведении 1:10 в сочетании с салицилатом хитозана $(0,1 \%)$ (см. рис.).

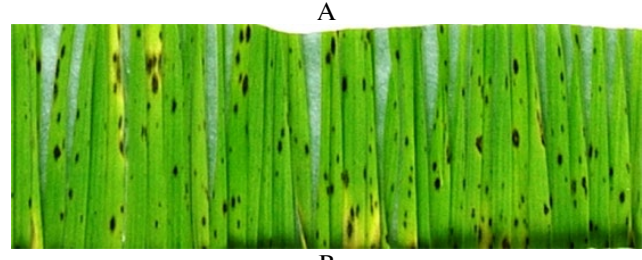

B

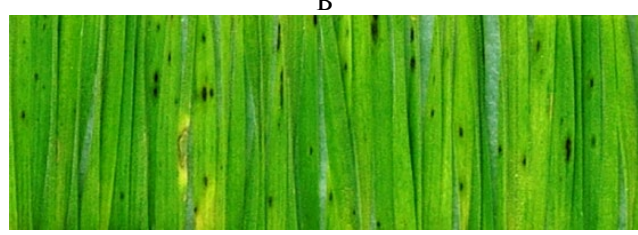

Д

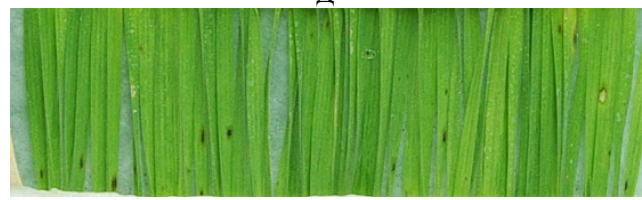

В - Витаплан, КЖ + коллоидный хитин (40 \%), Г - Витаплан, КЖ + салицилат хитозана (20\%), Д - салицилат хитозана (10\%).

Эффективность биопрепарата в защите пшеницы от темно-бурой пятнистости определяется двумя механизмами: прямым подавлением возбудителя болезни за счет синтеза антибиотиков и ферментов штаммами-продуцентами и опосредованно, через индукцию системной устойчивости. По нашему мнению, существуют значительные различия в механизмах защиты пшеницы от темно-бурой пятнистости при применении Витаплана, КЖ и его препаративных форм, содержавшей коллоидный хитин и $0,1 \%$ салицилат хитозана.

Биопрепарат Витаплан, КЖ на основе штаммов B. subtilis BKM В2604D и B. subtilis BKM B-2605D подавляет развитие болезни благодаря высокой фунгистатической активности по отношению к C. sativus, обусловленной синтезом метаболитного комплекса сложного состава, который включает пептидные и полиеновые антибиотики. Напротив, индуцирующая активность препарата была невысокой (см. табл. 2). Включение коллоидного хитина и салицилата хитозана в состав препаративных форм Витаплана снижало развитие болезни в 1,5-3,0 раза по отношению к контролю в зависимости от инфекционной нагрузки. Основной защитный механизм, обеспечивающий высокую биологическую активность препаративной формы, сочетающей Витаплан, КЖ (1:10) и салицилат хитозана $(0,1 \%),-$ индуцированная устойчивость. Фунгистатическая активность этого состава была несколько ниже, чем у Витаплана, КЖ (1:10). Биологическая активность препаративной формы, сочетающей Витаплан, КЖ (1:10) с коллоидным хитином $(1,0 \%)$, по-видимому, определялась совмещением фунгицидной активности препарата и индукции защитных реакций растения. Таким образом, разработанные нами препаративные формы 
Витаплана, КЖ обеспечивали прямое подавление развития возбудителя болезни и оказывали опосредованное защитное действие через повышение болезнеустойчивости растений пшеницы к темно-бурой пятнистости.

Согласно современным представлениям, микробно-растительные взаимоотношения в системе растение-фитопатоген-антагонист носят сложный и разнонаправленный характер. Например, штамм B. subtilis 26Д индуцировал системную устойчивость в растениях пшеницы, инфицированных гемибиотрофным грибом Septoria nodorum, и в растениях картофеля, пораженных оомицетом Phytophthora infestans, через накопление $\mathrm{H}_{2} \mathrm{O}_{2}$ и увеличение транскрипционной активности CK-регулируемых генов PRбелков, а также повышение активности пероксидазы и отложение лигнина в местах инфицирования (40).

Элиситорами, запускающими защитные механизмы растения, могут быть белки, липопептиды, полисахариды и другие соединения, ассоциированные с клеточной стенкой B. subtilis (41). Бактериальные метаболиты, обладающие свойствами индуцированной устойчивости, включают цепочку взаимосвязанных друг с другом защитных реакций, в том числе образование активных форм кислорода, фосфорилирование белков, запуск базовых механизмов фитоиммунитета, которые приводят к развитию системной устойчивости (42-45).

Хитин и хитозан - молекулярные детерминанты многих фитопатогенных микроорганизмов, которые распознаются белковыми рецепторами растений (46). В результате взаимодействия с рецепторами активируется комплекс защитных реакций неспецифического иммунитета растений и формируется системная устойчивость к патогенам. Индуцируемые защитные реакции включают генерацию активных форм кислорода (АФК), синтез каллозы, укрепление клеточной стенки лигнином, развитие реакции сверхчувствительности (СЧ-реакция), которая вызывает гибель растительных клеток и патогена в зоне его внедрения, индукцию генов, вовлеченных в синтез защитных белков, а также синтез 18 классов патогениндуцируемых белков с антимикробной (тионины, дефензины, ингибиторы протеиназ) и литической активностью (хитиназы, глюканазы), индукцию гормонов защиты (абсцизовой кислоты, жасмонатов, салициловой кислоты), а также индукцию фенол-пропаноидного пути и повышение уровня фитоалексинов (47).

Известно, что один из механизмов, связанных с повышением устойчивости растений табака, - возрастание количества СК под влиянием обработки штаммом B. pumilus SE34 (48). Поскольку CK - сигнальная молекула, включающая каскад защитных реакций в растениях, экзогенное применение СК совместно с Pseudomonas fluorescence (pf4-92) усилило индуцирующую активность антагониста в защите проростков нута от фузариозного увядания (49). Совместное применение P. fluorescence (SE21 и RD41) и индукторов устойчивости (хитин и салициловая кислота) стимулировало рост растений и повышало эффективность биологического контроля ризоктониоза перца (50). Опубликованы работы, подтверждающие, что сочетание микробов-антагонистов и хитозана повышало эффективность биоагентов в защите овощных культур и клубники от мучнистой росы (51). Добавление хитина к культуре штамма Bacillus sp. позволило значительно снизить увядание хлопка (52).

Очевидно, что разработка новых микробиологических средств защиты растений от болезней должна быть направлена на создание полифункциональных композиций, эффективных в отношении широкого круга 
фитопатогенов. Проведенные нами ранее исследования показали, что совместное использование штаммов микроорганизмов и хитозановых комплексов эффективно для защиты пшеницы от комплекса основных болезней, включающего корневую гниль и листовые пятнистости, а также для повышения урожайности (53).

Итак, в результате проведенных исследований получены две новые препаративные формы - Витаплан, КЖ + коллоидный хитин и Витаплан, КЖ + салицилат хитозана с повышенной биоцидной и индуцирующей активностью по сравнению с исходной формой Витаплан, КЖ. Препаративная форма Витаплан, КЖ + коллоидный хитин характеризуется высокой антагонистической активностью. Введение коллоидного хитина $(1,0 \%)$ в среду для глубинного культивирования штаммов-продуцентов обеспечивало эффективное подавление роста мицелия возбудителя темнобурой пятнистости пшеницы Cochliobolus sativus (до 84,9-88,1 \%), а индуцирующий эффект этой формы при защите пшеницы был в 1,5-2,0 раза выше по сравнению с таковым у исходного биопрепарата. Композиция, полученная добавлением 0,1 \% салицилата хитозана в Витаплан, КЖ, повышала биологическую активность Витаплана, КЖ в 2,0-2,5 раза. Экспериментально установленный высокий защитный эффект новой оптимизированной препаративной формы биопрепарата Витаплана, КЖ по отношению к C. sativus, по-видимому, был результатом совместного действия комплекса метаболитов штаммов B. subtilis, подавляющих или замедляющих рост фитопатогена, и повышения элиситорной активности в результате включения в состав композиции хитозановых индукторов болезнеустойчивости. Полученные результаты свидетельствуют о перспективности сочетания активных штаммов микроорганизмов-антагонистов возбудителей болезней растений и хитозановых комплексов для повышения биологической эффективности и расширения спектра действия разрабатываемых препаративных форм.

\section{ЛИТЕРАТ УРА}

1. Павлюшин В.А., Тютерев С.Л., Попова Э.В., Новикова И.И., Быкова Г.А., Домнина Н.С. Новые комплексные биопрепараты для защиты овощных культур от грибных и бактериальных болезней. Биотехнология, 2010, 4: 69-80.

2. Beneduzi A., Ambrosini A., Passaglia L.M.P. Plant growth-promoting rhizobacteria (PGPR): their potential as antagonists and biocontrol agents. Genetics and Molecular Biology, 2012, 35(4): 1044-1051 (doi: 10.1590/s1415-47572012000600020).

3. Kumar P., Dubey R.C., Maheshwari D.K. Bacillus strains isolated from rhizosphere showed plant growth promoting and antagonistic activity against phytopathogens. Microbiological Research, 2012, 167(1): 493-499 (doi: 10.1016/j.micres.2012.05.002).

4. Новикова И.И. Полифункциональные биопрепараты для фитосанитарной оптимизации агроэкосистем в биологическом земледелии. Мат. науч.-практ. конф. «Технологии и технические средства механизированного производства продукции растениеводства и животноводства». СПб, 2019, вып. 2(99): 183-194 (doi: 10.24411/0131-5226-2019-10162).

5. Ye Y.F., Li Q.Q., Fu G., Yuan G.Q., Miao J.H., Lin W. Identification of antifungal substance (Iturin A2) produced by Bacillus subtilis B47 and its effect on southern corn leaf blight. Journal of Integrative Agriculture, 2012, 11(9): 90-99 (doi: 10.1016/S1671-2927(12)60786-X).

6. Dunlap C.A., Schisler D.A., Bowman M.J., Rooney A.P. Genomic analysis of Bacillus subtilis $\mathrm{OH} 131.1$ and co-culturing with Cryptococcus lavescens for control of Fusarium head blight. Plant Gene, 2015, 2: 1-9 (doi: 10.1016/j.plgene.2015.03.002).

7. Zalila-Kolsi I., Mahmoud A.B., Ali H., Sellami S., Nasfi Z., Tounsi S., Jamoussi K. Antagonist effects of Bacillus spp. strains against Fusarium graminearum for protection of durum wheat (Triticum turgidum L. subsp. durum). Microbiological Research, 2016, 192(6): 148-158 (doi: 10.1016/j.micres.2016.06.012).

8. Yang L., Quan X., Xue B., Goodwin P.H., Lu S., Wang J., Du W., Wu C. Isolation and identiication of Bacillus subtilis strain YB-05 and its antifungal substances showing antagonism against Gaeumannomyces graminis var. tritici. Biological Control, 2015, 85: 52-58 (doi: 
10.1016/j.biocontrol.2014.12.010).

9. Gao X., Gong Y., Huo Y., Han Q., Kang Z., Huang L. Endophytic Bacillus subtilis strain E1R$\mathrm{J}$ is a promising biocontrol agent for wheat powdery mildew. Journal of Biomedicine and Biotechnology, 2015(6): 462645 (doi: 10.1155/2015/462645).

10. Li H., Zhao J., Feng H., Huang L., Kang Z. Biological control of wheat stripe rust by an endophytic Bacillus subtilis strain E1R-j in greenhouse and field trials. Crop Protection, 2013, 43: 201-206 (doi: 10.1016/j.cropro.2012.09.008).

11. Kalappanavar I.K., Patidar R.K., Kulkarni S. Management strategies of leaf rust of wheat caused by Puccinia recondita f. sp. tritici Rob. ex. Desm. Karnataka Journal of Agricultural Sciences, 2008, 21(1): 61-64.

12. Reiss A., Jørgensen L.N. Biological control of yellow rust of wheat (Puccinia striiformis) with Serenade ${ }^{\circ} A S O$ (Bacillus subtilis strain QST713). Crop Protection, 2017, 93: 1-8 (doi: 10.1016/j.cropro.2016.11.009).

13. Junior I., Schafer J.T., Corrêa B.O., Funck G.D., Moura A.B. Expansion of the biocontrol spectrum of foliar diseases in rice with combinations of rhizobacteria. Revista Ciência Agronômi$c a, 2017,48(3)$ : 513-522 (doi: 10.5935/1806-6690.20170060).

14. Akram W., Anjum T., Ali B. Searching ISR determinant/s from Bacillus subtilis IAGS174 against Fusarium wilt of tomato. BioControl, 2015, 60: 271-280 (doi: 10.1007/s10526-014-9636-1).

15. Tan S.Y., Jiang Y., Song S., Huang J.F., Ling N., Xu Y.C., Shen Q.R. Two Bacillus amyloliquefaciens strains isolated using the competitive tomato root enrichment method and their effects on suppressing Ralstonia solanacearum and promoting tomato plant growth. Crop Protection, 2013, 43: 134-140 (doi: 10.1016/j.cropro.2012.08.003).

16. Cao Y., Xu Z., Ling N., Yuan Y., Yang X., Chen L., Shen B., Shen Q. Isolation and identification of lipopeptides produced by B. subtilis SQR 9 for suppressing Fusarium wilt of cucumber. Scientia Horticulturae, 2012, 135: 32-39 (doi: 10.1016/j.scienta.2011.12.002).

17. Lee K.J., Kamala-Kannan S., Han S.S., Seong C.K., Lee G.W. Biological control of Phytophthora blight in red pepper (Capsicum annuum L.) using Bacillus subtilis. World Journal of Microbiology and Biotechnology, 2008, 24(7): 1139-1145 (doi: 10.1007/s11274-007-9585-2).

18. Cortez F.M., Chan-Cupul W., Buenrostro Nava M., Hernández-Ortega H. A., ManzoSánchez G., Galindo-Velasco E. Biological control of late leaf rust disease (Puccini astrum americanum (Farl.) Arthur) in raspberry (Rubus idaeus L.) using two biological products: Bacillus subtilis (Fungizard ${ }^{\circledR}$ ) and Larrea tridentata botanic extract (CleanCrop ${ }^{\circledR}$ ) under screenhouse conditions. Idesia (Arica), 2019, 37(1): 125-133 (doi: 10.4067/s0718-34292019005000504).

19. Wang X.Q, Zhao D.L., Shen L. L., Jing C L., Zhang C.S Application and mechanisms of Bacillus subtilis in biological control of plant disease. In: Role of rhizospheric microbes in soil /V.S. Meena (ed.). Springer, Singapore, 2018: 225-250 (doi: 10.1007/978-981-10-8402-7_9).

20. Wang L.-Y., Xie Y.-S., Cui Y.-Y., Xu J., He W., Chen H.-G., Guo J.-H. Conjunctively screening of biocontrol agents (BCAs) against fusarium root rot and fusarium head blight caused by Fusarium graminearum. Microbiological Research, 2015, 177: 34-42 (doi: 10.1016/j.micres.2015.05.005).

21. Новикова И.И., Бойкова И.В., Павлюшин В.А., Зейрук В.Н., Васильева С.В., Азизбекян Р.Р., Кузнецова Н.И. Перспективы использования биопрепаратов на основе микробов-антагонистов для защиты картофеля от болезней при хранении. Вестник защиты растений, 2013, 4: 12-21.

22. Li S., Zhang N., Zhang Z., Luo J., Shen B., Zhang R., Shen Q. Antagonist Bacillus subtilis HJ5 controls Verticillium wilt of cotton by root colonization and biofilm formation. Biology and Fertility of Soils, 2013, 49(3): 295-303 (doi: 10.1007/s00374-012-0718-x).

23. Yu X., Ai C., Xin L., Zhou G. The siderophore-producing bacterium, Bacillus subtilis CAS15, has a biocontrol effect on Fusarium wilt and promotes the growth of pepper. European Journal of Soil Biology, 2011, 47(2): 138-145 (doi: 10.1016/j.ejsobi.2010.11.001).

24. Wang T., Liang Y., Wu M., Chen Z., Lin J., Yang L. Natural products from Bacillus subtilis with antimicrobial properties. Chinese Journal of Chemical Engineering, 2015, 23(4): 744-754 (doi: 10.1016/j.cjche.2014.05.020).

25. Сидорова Т.М., Асатурова А.М., Хомяк А.И. Биологически активные метаболиты Bacillus subtilis и их роль в контроле фитопатогенных микроорганизмов. Сельскохозяйственная биология, 2018, 53(1): 29-37 (doi: 10.15389/agrobiology.2018.1.29rus).

26. Актуганов Г.Э., Галимзянова Н.Ф., Мелентьев А.И., Кузьмина Л.Ю. Внеклеточные гидролазы штамма Basillus sp. 739 и их участие в лизисе клеточных стенок микромицетов. Микробиология, 2007, 76(4): 471-479.

27. Van der Ent S., van Wees S.C.M., Pieterse C.M.J. Jasmonate signaling in plant interactions with resistance-inducing beneficial microbes. Phytochemistry, 2009, 70(13-14): 1581-1588 (doi: 10.1016/j.phytochem.2009.06.009).

28. Van Loon L.C. Plant responses to plant growth-promoting rhizobacteria. European Journal of Plant Pathology, 2007, 119(3): 243-254 (doi: 10.1007/s10658-007-9165-1).

29. De Vleesschauwer D., Höfte M. Rhizobacteria-induced systemic resistance. Advances in Botanical Research, 2009, 51: 223-281 (doi: 10.1016/S0065-2296(09)51006-3). 
30. Ryu C.M., Farag M.A., Hu C.H., Reddé M.S., Kloepper J.W., Parй P.W. Bacterial volatiles induce systemic resistance in Arabidopsis. Plant Physiology, 2004, 134(3): 1017-1026 (doi: 10.1104/pp.103.026583).

31. Novikova I.I., Shenin Y.D. Isolation, identification, and antifungal activity of a Gamair complex formed by Bacillus subtilis M-22, a producer of a biopreparation for plant protection from mycoses and bacterioses. Applied Biochemistry and Microbiology, 2011, 47(9): 817-826 (doi: 10.1134/S0003683811090031).

32. Badawy M.E.I., Rabea E.I. A biopolymer chitosan and its derivatives as promising antimicrobial agents against plant pathogens and their applications in crop protection. International Journal of Carbohydrate Chemistry, 2011, 2011: 460381 (doi: 10.1155/2011/460381).

33. Тютерев С.Л. Экологически безопасные индукторы устойчивости растений к болезням и физиологическим стрессам. Вестник защиты растений, 2015, 1: 3-13.

34. Варламов В.П., Немцев С.В., Тихонов В.Е. Хитин и хитозан: природа, получение и применение. М., 2010.

35. Васюкова Н.И., Озерецковская О.Л. Индуцированная устойчивость растений и салициловая кислота. Прикладная биохимия и микробиология, 2007, 43(4): 405-411.

36. Попова Э.В., Коваленко Н.М., Сокорнова С.В., Тютерев С.Л., Домнина Н.С. Влияние гибридных производных хитозана на устойчивость пшеницы к патогенам с разной стратегией питания. Прикладная биохимия и микробиология, 2018, 54(5): 540-545 (doi: 10.1134/S055510991805015X).

37. Muzzarelli R.A.A. Chitin. Pergamon Press, Oxford, 1977.

38. Roberts W.K., Selitrennikoff C.P. Plant and bacterial chitinases differin antifungal activity. Journal of General Microbiology, 1988, 134(1): 169-176 (doi: 10.1099/00221287-134-1-169).

39. Михайлова Л.А., Мироненко Н.В., Коваленко Н.М. Желтая пятнистость пшеницы. Методические указания по изучению популяций возбудителя желтой пятнистости Pyrenophora tritici-repentis и устойчивости сортов. СПб, 2012.

40. Максимов И.В., Абизгильдина Р.Р., Сорокань А.В., Бурханова Г.Ф. Регуляция пероксидазной активности под влиянием сигнальных молекул и Bacillus subtilis 26Д инфицированных Phytophthora infestans растениях картофеля. Прикладная биохимия и микробиология, 2014, 50(2): 197-202 (doi: 10.7868/S0555109914020135).

41. Veselova S.V., Nuzhnaya T.V., Maksimov I.V. Role of jasmonic acid in interaction of plants with plant growth promoting rhizobacteria during fungal pathogenesis. In: Jasmonic acid: biosynthesis, functions and role in plant development. Morrison L. (ed.). Nova Sciense, New York, 2015.

42. Aloni R., Aloni E., Langhans M., Ullrich C.I. Role of cytokinin and auxin in shaping root architecture: regulating vascular differentiation, lateral root initiation, root apical dominance and root gravitropism. Annals of Botany, 2006, 97(5): 883-893 (doi: 10.1093/aob/mcl027).

43. Yarullina L.G., Kasimova R.I., Ibragimov R.I., Akhatova A.R., Umarov I.A., Maksimov I.V. Qualitative and quantitative changes of potato tuber proteome under the influence of signal molecules and infection with Phytophthora infestans. Applied Biochemistry and Microbiology, 2016, 52(1): 71-78 (doi: 10.1134/S0003683816010154).

44. Vandeputte O., Öden S., Mol A., Vereecke D., Goethals K., El Jaziri M., Prinsen E. Biosynthesis of auxin by the Gram-positive phytopathogen Rhodococcus faseians is controlled by compounds specific to infected plant tissues. Applied and Environmental Microbiology, 2005, 71(3): 1169-1177 (doi: 10.1128/AEM.71.3.1169-1177.2005).

45. Iriti M., Faoro F. Chitosan as a MAMP, searching for a PRR. Plant Signaling \& Behavior, 2009, 4(1): 66-68 (doi: 10.4161/psb.4.1.7408).

46. Deepmala K., Hemantaranjan A., Bharti S., Nishant Bhanu A. A future perspective in crop protection: chitosan and its oligosaccharides. Advances in Plants \& Agriculture Research, 2014, 1(1): 23-30 (doi: 10.15406/apar.2014.01.00006).

47. El Hadrami A., Adam L.R., El Hadrami I., Daayf F. Chitosan in plant protection. Marine Drugs, 2010, 8(4): 968-987 (doi: 10.3390/md8040968).

48. Zhang S., Moyne A.-L., Reddy M.S, Joseph W., Kloepper J.W. The role of salicylic acid in induced systemic resistance elicited by plant growth-promoting rhizobacteria against blue mold of tobacco. Biological Control, 2002, 25(3): 288-296 (doi: 10.1016/S1049-9644(02)00108-1).

49. Saikia R., Singh T., Kumar R., Srivastava J., Srivastava A.K., Singh K., Arora D.K. Role of salicylic acid in systemic resistance induced by Pseudomonas fluorescens against Fusarium oxysporum f. sp. ciceri in chickpea. Microbiological Research, 2003, 158(3): 203-213 (doi: 10.1078/0944-5013-00202).

50. Rajkumar M., Lee K.J., Freitas H. Effects of chitin and salicylic acid on biological control activity of Pseudomonas spp. against damping off of pepper. South African Journal of Botany, 2008, 74(2): 268-273 (doi: 10.1016/j.sajb.2007.11.014).

51. Abdel-Kader M.M., El-Mougy N.S., Aly M.D.E., Lashin S.M. Integration of biological and fungicidal alternatives for controlling foliar diseases of vegetables under greenhouse conditions. International Journal of Agriculture and Forestry, 2012, 2(2): 38-48 (doi: 10.5923/j.ijaf.20120202.07).

52. Rajendran L., Samiyappan R. Endophytic Bacillus species confer increased resistance in cotton against damping off disease caused by Rhizoctonia solani. Plant Pathology Journal, 2008, 7(1): 112 (doi: 10.3923/ppj.2008.1.12). 
53. Колесников Л.Е., Попова Э.В., Новикова И.И., Прияткин Н.С., Архипов М.В., Колесникова Ю.Р., Потрахов Н.Н., Van Duijn В., Гусаренко А.С. Совместное использование штаммов микроорганизмов и хитозановых комплексов для повышения урожайности пшеницы (Triticum aestivum L.). Сельскохозяйственная биология, 2019, 54(5): 1024-1040 (doi: 10.15389/agrobiology.2019.5.1024rus).

ФГБНУ Всероссийский НИИ защиты растений,

196608 Россия, г. Санкт-Петербург-Пушкин, ш. Подбельского, 3, e-mail: irina_novikova@inbox.ru $₫$, elzavpopova@mail.ru,

krasnobaeva08@mail.ru,nadyakov@mail.ru
Поступила в редакцию 27 июля 2020 года

Sel'skokhozyaistvennaya biologiya [Agricultural Biology], 2021, V. 56, № 3, pp. 511-522

\section{BIOLOGICAL BACKGROUND TO USING CHITOSAN INDUCERS TO INCREASE THE EFFICIENCY OF BIOFUNGICIDES}

\section{I.I. Novikova ${ }^{\bowtie}$, E.V. Popova, I.L. Krasnobaeva, N.M. Kovalenko}

All-Russian Research Institute of Plant Protection, 3, sh. Podbel'skogo, St. Petersburg, 196608 Russia, e-mail irina_novikova@inbox.ru (corresponding author $\varangle$ ), elzavpopova@mail.ru, krasnobaeva08@mail.ru,nadyakov@mail.ru ORCID:

Novikova I.I. orcid.org/0000-0003-2816-2151

Popova E.V. orcid.org/0000-0003-3165-6777

The authors declare no conflict of interests

Received July 27, 2020
Krasnobaeva I.L. orcid.org/0000-0001-9166-4475

Kovalenko N.M. orcid.org/0000-0001-9577-8816

doi: 10.15389/agrobiology.2021.3.511eng

\section{Abstract}

Microbiological preparations form the basis of modern technologies phytosanitary optimization of agroecosystems, therefore, increasing their efficiency in protecting crops from a wide range of plant pathogens is an urgent task of crop production. The All-Russian Research Institute of Plant Protection (VIZR) has developed Vitaplan, a biological product based on the composition of two strains, the Bacillu subtilis VKM B-2604D and B. subtilis VKM B-2605D with a different composition of active complexes and a mechanism of action that are highly effective against a wide range of plant pathogens. The aim of the study is to substantiate increasing the biological effectiveness of new Vitaplan formulations supplemented with chitosan as an inducers of plant resistance. In this work, for the first time, two new formulations were developed, the Vitaplan, $\mathrm{CF}+$ colloidal chitin and the Vitaplan, $\mathrm{CF}+0.1 \%$ chitosan salicylate with increased antagonistic and elicitor activity compared to the original biological Vitaplan, CF. The effect of disease resistance inducers, such as colloidal chitin and chitosan salicylate, on the biological activity of Vitaplan has been investigated. The colloidal chitin $(1 \%)$ added to the deep culture medium increased the antagonistic activity of $B$. subtilis VKM B-2604D and VKM B-2605D against the tomato bacterium Clavibacter michiganensis subsp. Michiganensis (Smith) Davis et al. (strain 101) and the fungus Alternaria solani Sorauer, and also ensured effective suppression of the growth of Cochliobolus sativus mycelium up to $84.9-88.1 \%$ on day 5 and day 7 of the experiment, which is comparable to the efficiency of Vitaplan CF (80.9$87.5 \%$, respectively). Chitosan salicylate at a concentration of $0.1 \%$ had a moderate fungistatic activity, with only 36.5-46.0 \% suppression of the growth of the $C$. sativus mycelium. The study of the immunomodulatory activity of various Vitaplan CF preparative forms in protecting wheat against the brown spot pathogen Cochliobolus sativus (S. Ito \& Kurib.) was carried out under various infectious loads. Depending on the infectious load of the pathogen, preliminary spraying of wheat plants with Vitaplan, $\mathrm{CF}$ at a dilution of 1:10 followed by infection with the brown spot pathogen reduced the leaf lesion area to 50-80\% compared to 65-100\% in control. Adding $1.0 \%$ colloidal chitin to the culture medium for the producer strains reduced leaf damage to 40-50\%, which indicates a higher immunomodulatory activity of this form of Vitaplan compared to Vitaplan CF at a dilution of 1:10. Chitosan salicylate proved to be an effective inducer of disease resistance, reducing damage to wheat plants by dark brown spots to $10-20 \%$, depending on the infectious load. The addition of chitosan salicylate at a concentration of $0.1 \%$ to original form Vitaplan, CF at a 1:10 dilution also had a positive effect on the antagonist with a 2.0-2.5-fold increase of its biological activity. The biological effectiveness of the new formulation Vitaplan CF (1:10) + chitosan salicylate $(0.1 \%)$ in protecting wheat from brown spot when spraying plants is determined by two mechanisms, i.e., by i) direct pathogen suppression due to antibiotics and enzymes the B. subtilis VKM B-2604D and B. subtilis VKM B-2605D produce, and ii) through the induction of plant systemic resistance. The chitosan salicylate in the Vitaplan biological increases the inducing activity of this new formulation compared to the original form. Thus, the prospect of combining active selected strains of microbial antagonists of plant pathogens and chitosan complexes to increase the biological efficiency and expand the spectrum of action of drugs has been experimentally confirmed and theoretically substantiated.

Keywords: biological control, Bacillus subtilis, Vitaplan formulations, fungistatic activity, antagonistic effect, chitosan, chitin, systemic resistance, Triticum aestivum L., Cochliobolus sativus. 